\title{
Nitrate removal from groundwater using solid-phase denitrification process without inoculating with external microorganisms
}

\author{
X. M. Wang $\cdot$ J. L. Wang
}

Received: 28 August 2011/Revised: 18 January 2012/ Accepted: 29 April 2012/Published online: 20 March 2013

(C) Islamic Azad University (IAU) 2013

\begin{abstract}
Denitrification of groundwater was studied using a laboratory-scale reactor packed with biodegradable snack ware served as both carbon source and biofilm support for microorganisms. The complete removal of 50 $\mathrm{mg} / \mathrm{L}$ of nitrate-nitrogen was achieved in a 23-day-old reactor with $2.1 \mathrm{~h}$ of hydraulic retention time without inoculating with any external microorganisms, which indicates that indigenous microorganisms in groundwater proliferate readily and result in stable biofilm formation onto biodegradable snack ware. Accumulation of nitrite and nitrate residue was detected when hydraulic retention time was lower than $2.1 \mathrm{~h}$. The breakthrough of nitratenitrogen up to over $10 \mathrm{mg} / \mathrm{L}$ in the effluent water was observed with nitrate removal efficiency reducing to about $75 \%$ when hydraulic retention time was lowered to $1.4 \mathrm{~h}$. The highest rate of denitrification was observed with $1.5 \mathrm{~h}$ of hydraulic retention time. Dissolved organic carbon concentration in the effluent water ranged between 10 and $20 \mathrm{mg} / \mathrm{L}$ during the stable operation of the reactor, and nitrite-nitrogen concentration was never higher than $0.09 \mathrm{mg} / \mathrm{L}$. Considering its relatively low price and high denitrification rate, biodegradable snack ware can become a good alternative for denitrification process.
\end{abstract}

\section{M. Wang}

Department of Microbial Biotechnology,

Beijing Agro-Biotechnology Research Center,

Beijing Academy of Agriculture and Forestry Sciences,

Beijing 100097, People's Republic of China

\section{J. L. Wang ( $\square)$}

Laboratory of Environmental Technology,

Institute of Nuclear and New Energy Technology (INET),

Tsinghua University, Tsinghuayuan, Haidian District,

Beijing 100084, People's Republic of China

e-mail:wangj1@tsinghua.edu.cn
Keywords Biofilm support - Carbon source · Denitrification rate $\cdot$ Hydraulic retention time

\section{Introduction}

In the past decades, considerable increase in nitrate concentration in groundwater has been observed in many countries, including China (Ovez 2006; Rocca et al. 2007; Sierra-Alvarez et al. 2007; Wang and Wang 2009). Concern over nitrate contamination is due to health problems related to methemoglobinemia in infants (blue baby syndrome) because nitrate converts to nitrite in the body and reacts with $\mathrm{Fe}(\mathrm{II})$ in hemoglobin to oxidize it to $\mathrm{Fe}(\mathrm{III})$, which limits the oxygen carrying capacity of blood. In addition, consuming nitrate-contaminated water can result in cancer of the alimentary canal (Vosoughifar et al. 2005; Aslan and Turkman 2006). As a result, relevant standards have been set for nitrate content in drinking water by various agencies. The United States Environmental Protection Agency (USEPA) has set maximum contaminant levels (MCLs) of $10 \mathrm{mg}$ nitrate-nitrogen $\left(\mathrm{NO}_{3}-\mathrm{N}\right) / \mathrm{L}$, and The World Health Organization (WHO) and the European Economic Community (EEC) have set standards of $11.3 \mathrm{mg} \mathrm{NO}$ - $\mathrm{N} / \mathrm{L}$.

Nitrate pollution of groundwater is caused mostly by intensive use of nitrogen-based fertilizers in agriculture and uncontrolled land discharges of raw and treated wastewater (Shrimali and Singh 2001). China is one of the largest developing countries with a long agricultural history in the world. To meet food demands for increasingly growing population, input amounts of chemical fertilizers gradually increase year by year in China, for example, nitrogen fertilizers from $270 \mathrm{~kg} \mathrm{~N} / \mathrm{ha}$ in 1998 to $366 \mathrm{~kg} \mathrm{~N} / \mathrm{ha}$ in 2002 (Wang et al. 2003). Excessive nitrogen-based fertilizer 
applications and the low utilization ratio (30-41\%) have led to an increase in $\mathrm{NO}_{3}-\mathrm{N}$ concentration in the groundwater in the most of regions in China (Wang et al. 2002; Chen et al. 2007).

Conventional drinking water treatment processes are not adequate to remove nitrate from groundwater due to its stability and solubility with low potential for coprecipitation or adsorption. Concern about nitrate pollution has resulted in the development of many techniques. The typical processes can be grouped into chemical (chemical reduction), physical (reverse osmosis, electrodialysis), chemical-physical (ion exchange) and biological processes. Among these, microbial denitrification has been shown to be the most economical, efficient and environmentally sound and to be feasible on a large scale (Soares and Abeliovich 1998; Gómeza et al. 2002; Bidhendi et al. 2006). However, biodenitrification also has a risk of gaseous nitrous oxide production, a more potent green house gas than $\mathrm{CO}_{2}$.

The majority of microbial denitrification treatment relies on heterotrophic bacteria which require an organic carbon source. Groundwater has low carbon content; therefore, external carbon-containing substrates have to be added. Usually, dissolved carbon source such as ethanol, methanol or acetate is used as electron donors for nitrate reduction (Hoek and Klapwijk 1987; Green et al. 1994; Bandpi et al. 1999). The disadvantage of this treatment process is the need for a close, rather sophisticated process control, and has the risk of overdosing with the resultant deterioration of effluent water quality (Boley et al. 2000). To avoid the above-mentioned problems, a solid substrate as an alternative to the liquid carbon sources was employed in the denitrification process by some researchers in the recent years. For this type of denitrification, termed as "solid-phase denitrification" (SPD), solid substrates serve not only as constant sources of reducing power for denitrification but also as supporters favorable for development of microbial films (Hiraishi and Khan 2003). SPD process without adding soluble organic substrates avoids sophisticated system control, and is in favor of stable system operation (Wang and Wang 2009).

The main objective of this study is to investigate the efficiency of nitrate removal from groundwater using a continuous flow reactor packed with biodegradable snack ware (BSW) without inoculating with external microorganisms. Considering its relatively low prices and as a way to reuse of available resource, BSW can become a good alternative for denitrification process. This study was carried out between April 2009 and October 2009 in Beijing Agro-Biotechnology Research Center and Tsinghua University, China.

\section{Materials and methods}

\section{Materials}

BSW is made from reed and sugar cane, manufactured by Zhejiang Shuangyu Plastic Ltd., China. Cellulose is its main component. Prior to use, BSW was cut into pieces in sizes of $1.5 \mathrm{~cm} \times 1.5 \mathrm{~cm}$ with $0.478 \mathrm{~m}^{2} / \mathrm{g}$ of surface area. A synthetic influent water medium was used to simulate the composition of nitrate-contaminated groundwater, which consisted of the groundwater from Changping campus, Tsinghua University, China, containing about $50 \mathrm{mg} / \mathrm{L}$ of nitrogen and $10 \mathrm{mg} / \mathrm{L}$ of phosphorus by adding $\mathrm{NaNO}_{3}$ and $\mathrm{KH}_{2} \mathrm{PO}_{4}$, unless otherwise stated. The characteristics of groundwater used in the experiments are as follows: $\mathrm{NO}_{3}$ $\mathrm{N}$, 6.5-9.6 mg/L; dissolved oxygen (DO), $3.0-4.5 \mathrm{mg} / \mathrm{L}$; $\mathrm{NO}_{2}-\mathrm{N}, \quad 0.0 \mathrm{mg} / \mathrm{L}$; dissolved organic carbon (DOC), $0.0-1.3 \mathrm{mg} / \mathrm{L}$; and $\mathrm{pH}$ 7.4-7.9.

\section{Experimental set-up}

The continuous experimental set-up consisted of a cylindrical plexiglass biodenitrification unit of $4.5 \mathrm{~cm}$ inner diameter and $40 \mathrm{~cm}$ height, completely submerged and operating with an upward flow mode. The flow rate was regulated by a peristaltic pump (BT00-100M, Baoding Lange Co., China) (Fig. 1). The reactor was packed with $60 \mathrm{~g}$ of BSW, and was started up with $2.1 \mathrm{~h}$ of hydraulic retention time (HRT), without inoculating with external microorganisms. Experimental study was carried out at room temperature $\left(24 \pm 2{ }^{\circ} \mathrm{C}\right)$ and $\mathrm{pH}$ 7.5. To establish anoxic conditions in the reactor, the system was airtight, and the influent was purged with high-purity nitrogen gas to keep dissolved oxygen (DO) concentration below $0.5 \mathrm{mg} / \mathrm{L}$. The reactor was covered with aluminum paper to prevent light penetration.

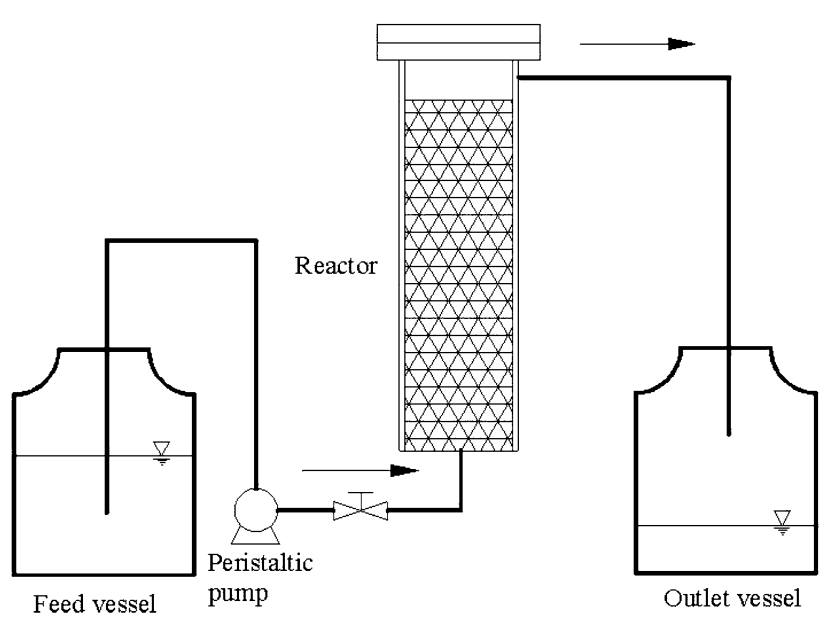

Fig. 1 Schematic representation of the experimental set-up 
Analytical determinations

The samples collected at regular intervals were filtered through $0.45-\mu \mathrm{m}$ pore membrane and were tested within $1 \mathrm{~h}$ of collection. The filtrate was subjected to analyses of concentrations of $\mathrm{NO}_{3}-\mathrm{N}, \mathrm{NO}_{2}-\mathrm{N}$, ammonia and DOC according to standard methods (SEPAC 2002). Dissolved organic carbon (DOC) concentration was determined by a TOC analyzer (TOC-V wp, Shimadzu). DO measurements were carried out using a WTW oxygen meter. The structure of the biofilm attached to BSW carrier after being washed with deionized water was examined by a scanning electron microscope (SEM, S-3400N, HITACHI, Japan). Colony forming units (CFU) of the effluent water were counted by standard plating techniques on nutritional agar (SEPAC 2002).

\section{Results and discussion}

Acclimation of denitrifiers to BSW without adding external microorganisms

Microorganisms should be inoculated to reactors when biodenitrification process with biofilm technology is employed to remove nitrate from drinking water. Generally, activated sludge is used as the seed of denitrifying bacteria (Mohseni-Bandpi and Elliot 1998; Moreno et al. 2005). For drinking water treatment, external microorganisms inoculated carry a potential risk of causing deterioration in effluent quality. To avoid this disadvantage, it was attempted to acclimatize denitrifiers from indigenous microorganisms in groundwater to BSW. The background values of bacterial counts for the groundwater used in the experiment ranged between 7 and $15 \mathrm{CFU} / \mathrm{mL}$. During the acclimation process, $\mathrm{NO}_{3}-\mathrm{N}$ concentrations in the influents increased gradually from 20 to $50 \mathrm{mg} / \mathrm{L}$, and HRT was

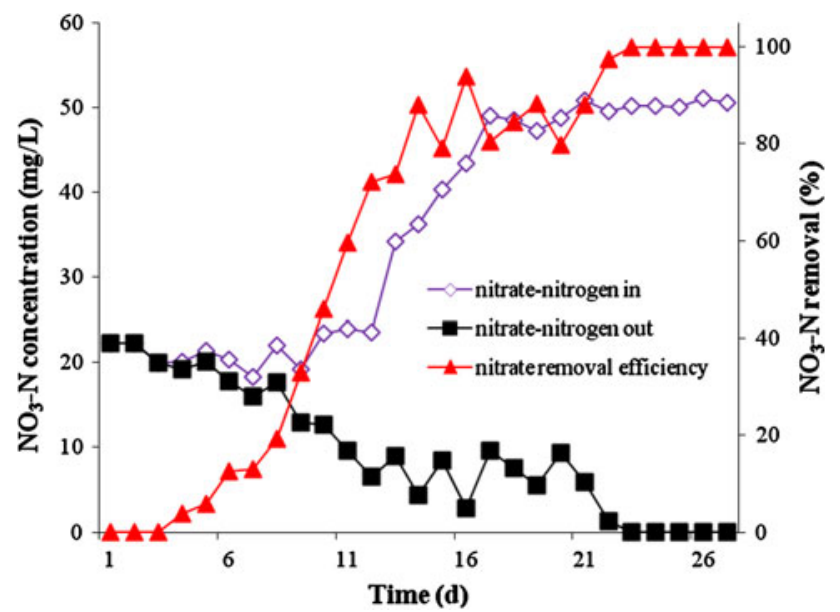

Fig. 2 Concentrations of $\mathrm{NO}_{3}-\mathrm{N}$ in the influent and effluent of the reactor packed with $60 \mathrm{~g} \mathrm{BSW}$ at $24 \pm 2{ }^{\circ} \mathrm{C}$ and $2.1 \mathrm{~h}$ of HRT
$2.1 \mathrm{~h}$. After 4-day continuous operation of the reactor, $\mathrm{NO}_{3}-\mathrm{N}$ elimination was observed (Fig. 2). The complete removal of approximate $50 \mathrm{mg} / \mathrm{L}$ of $\mathrm{NO}_{3}-\mathrm{N}$ was achieved on day 23. Meanwhile, it could be observed that the surface of BSW became rufous, which was due to biofilm coating onto BSW. SEM micrograph from biofilm samples collected after the start-up period of the reactor (Fig. 3) show at least two different morphologies (rods and cocci) colonizing the packing material.

The breakthrough of $\mathrm{NO}_{3}-\mathrm{N}$ up to over $10 \mathrm{mg} / \mathrm{L}$ in the effluent water was observed with nitrogen removal efficiency reducing to about $75 \%$ when HRT was lowered to $1.4 \mathrm{~h}$ between 31 and 34 days (Fig. 4). On 35 day and subsequently, $100 \%$ removal efficiency for $50 \mathrm{mg} / \mathrm{L}$ of $\mathrm{NO}_{3}-\mathrm{N}$ was recovered when HRT was increased back to $2.1 \mathrm{~h}$. This shows that a stable biofilm can be formed using BSW as the sole carbon source as well as the only physical support for indigenous microorganisms from groundwater.

The above-mentioned results indicate that the inoculation with external microorganisms is not necessary for the acclimation of denitrifiers in denitrification process supported by BSW. Indigenous bacteria in groundwater can proliferate readily under denitrifying conditions, and form stable biofilms onto BSW. Although this sort of denitrifiers acclimation may need longer time than inoculation with activated sludge due to the far lower bacterial counts in groundwater than in activated sludge, it will avoid the deterioration of the effluent water quality due to activated sludge addition; especially, it will prevent potential pathogenic bacteria in activated sludge from contaminating the groundwater treated.

\section{Denitrification efficiency and water quality}

As shown in Figs. 2 and 4, $\mathrm{NO}_{3}-\mathrm{N}$ never was detected in the continuously operational reactor between 23 and

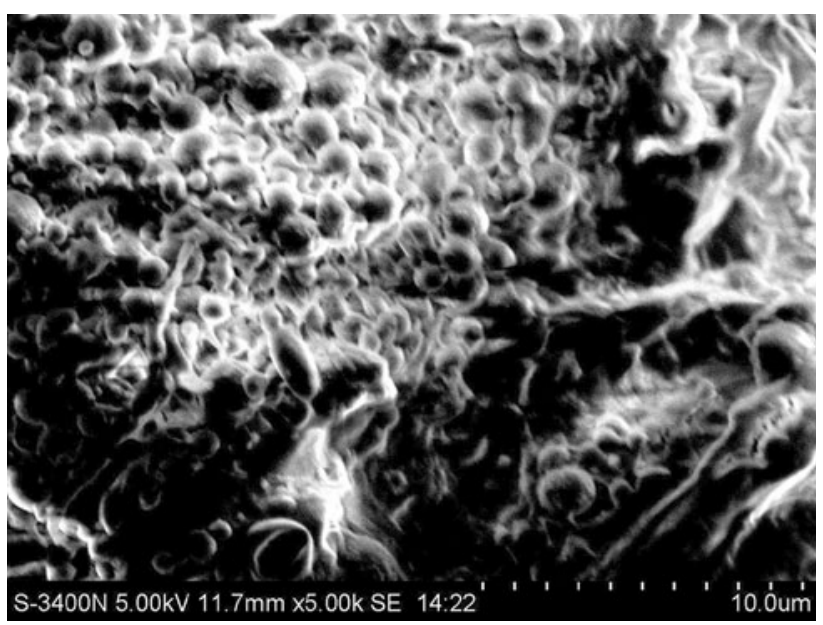

Fig. 3 SEM image of the biofilm attached onto the BSW carrier 


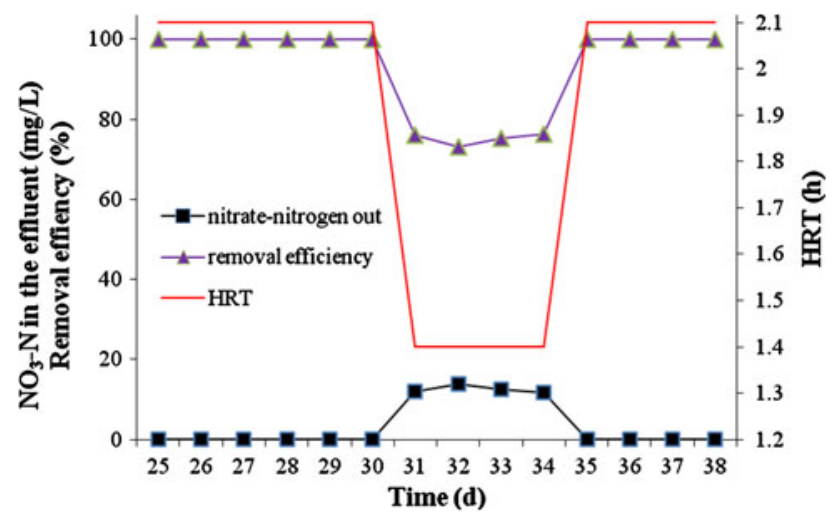

Fig. 4 Denitrification performance of the reactor with $50 \mathrm{mg} / \mathrm{L}$ of $\mathrm{NO}_{3}-\mathrm{N}$ in the influent water

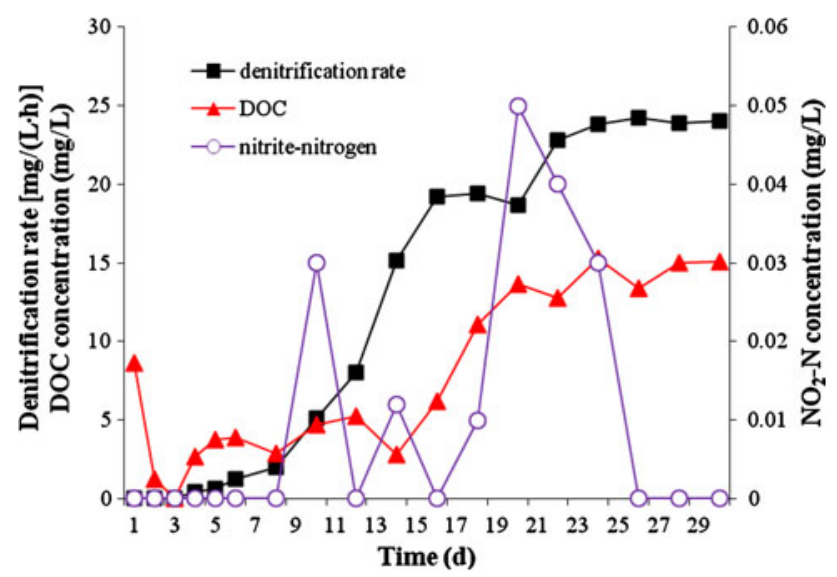

Fig. 5 Changes in concentrations of $\mathrm{NO}_{2}-\mathrm{N}$ and DOC in the effluent and denitrification rate of the reactor packed with $60 \mathrm{~g} \mathrm{BSW}$ at $24 \pm 2{ }^{\circ} \mathrm{C}$ and $2.1 \mathrm{~h}$ of HRT

30 days with $2.1 \mathrm{~h}$ of HRT. Nitrite was observed with a maximum value of $0.05 \mathrm{mg} / \mathrm{L}$ in the 20 -day-old reactor, and had never been observed during the period between 26 and 30 days (Fig. 5). DOC content in groundwater used in the experiment ranged between 0.2 and $1.3 \mathrm{mg} / \mathrm{L}$. DOC concentration in the effluent water increased up to approximate $9 \mathrm{mg} / \mathrm{L}$ in the first day, which was due to soluble fraction of BSW washed out of the reactor. From then on, a sharp decrease in DOC concentration took place since DOC was rapidly eluted by the influent; moreover, a fraction of DOC was assimilated by microorganisms in the groundwater. With the acclimation process proceeding, microorganisms in the groundwater gradually proliferated and attached onto BSW, which resulted in increases both in nitrate elimination and DOC release due to biodegradation of BSW. On day 18, DOC concentration surpassed $10 \mathrm{mg} / \mathrm{L}$, and from then on it was never below $10 \mathrm{mg} / \mathrm{L}$. When complete nitrate elimination was obtained after 23-day operation, DOC concentrations ranged between 13 and $16 \mathrm{mg} / \mathrm{L}$, with a volumetric denitrification rate of about $24 \mathrm{mg}\left(\mathrm{NO}_{3}-\mathrm{N}\right) /(\mathrm{L} \mathrm{h})$ (Fig. 5).

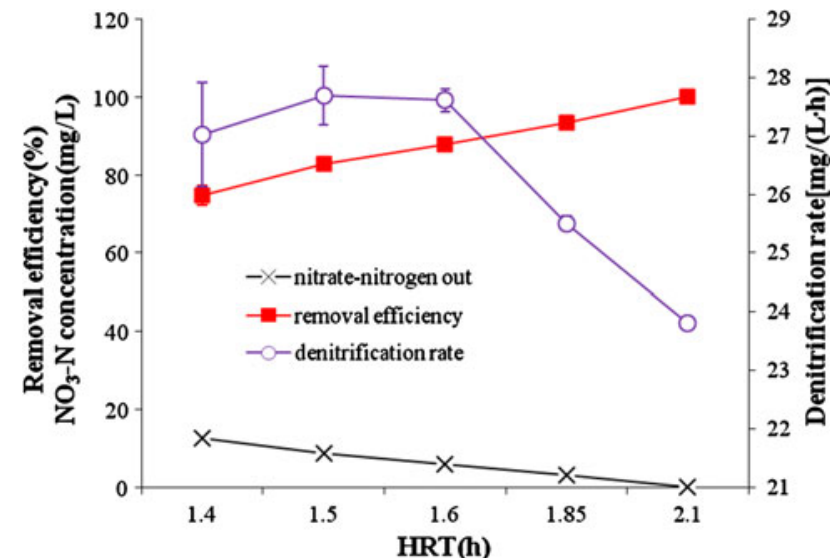

Fig. 6 Effects of HRT on denitrification rate, $\mathrm{NO}_{3}-\mathrm{N}$ removal efficiency and $\mathrm{NO}_{3}-\mathrm{N}$ concentration in the effluent with $50 \mathrm{mg} / \mathrm{L}$ of $\mathrm{NO}_{3}-\mathrm{N}$ in the influent ( $Y$ error indicates the standard error of means among three determinations)

The treated water never exhibited noticeable color and odor, and ammonia was never detected during the experiment. The number of CFU in the effluent was in the order of $10^{4} / \mathrm{mL}$, which is lower than that in denitrification with simple carbon sources (Soares and Abeliovich 1998).

\section{Effect of HRT on denitrification performance}

Many researchers have confirmed that denitrification rates are strongly dependent on HRT or flow rates (Soares and Abeliovich 1998; Kesseru et al. 2003; Aslan and Turkman 2006; Behera et al. 2007). Moreover, HRT affects nitrite accumulation in the effluent (Soares and Abeliovich 1998; Aslan and Turkman 2006). As shown in Fig. 5, when HRT was decreased to $1.4 \mathrm{~h}$, the $\mathrm{NO}_{3}-\mathrm{N}$ breakthrough was observed. To investigate intensively the effect of HRT on denitrification performance supported by BSW, 1.4, 1.5, 1.6, 1.85 and $2.1 \mathrm{~h}$ of HRT were set respectively, and the experimental results by continuous operation for each HRT for 3 days are illustrated in Figs. 6 and 7.

$\mathrm{NO}_{3}-\mathrm{N}$ concentration in the effluent was below $10 \mathrm{mg} / \mathrm{L}$ when HRT was higher than $1.5 \mathrm{~h}$, which meets drinking water standards. $\mathrm{NO}_{3}-\mathrm{N}$ concentration reached about $13 \mathrm{mg} / \mathrm{L}$ with $1.4 \mathrm{~h}$ of HRT, and nitrate removal efficiency dropped to $75 \%$. With the decrease in HRT from 2.1 to $1.5 \mathrm{~h}$, denitrification rate gradually increased up to about $27.7 \mathrm{mg} \mathrm{NO}-\mathrm{N} /(\mathrm{L} \mathrm{h})$; subsequently, denitrification rate had a slight decrease with the lower HRT (Fig. 6).

When HRT was decreased below $2.1 \mathrm{~h}, \mathrm{NO}_{2}-\mathrm{N}$ accumulation was observed with a maximum value of $0.09 \mathrm{mg} / \mathrm{L}$ for $1.4 \mathrm{~h}$ of HRT (Fig. 7). This may be because of the low contact time for microbial activity, resulting in intermediate accumulations of denitrification process (Aslan and Turkman 2006). Moreover, longer reaction time will 


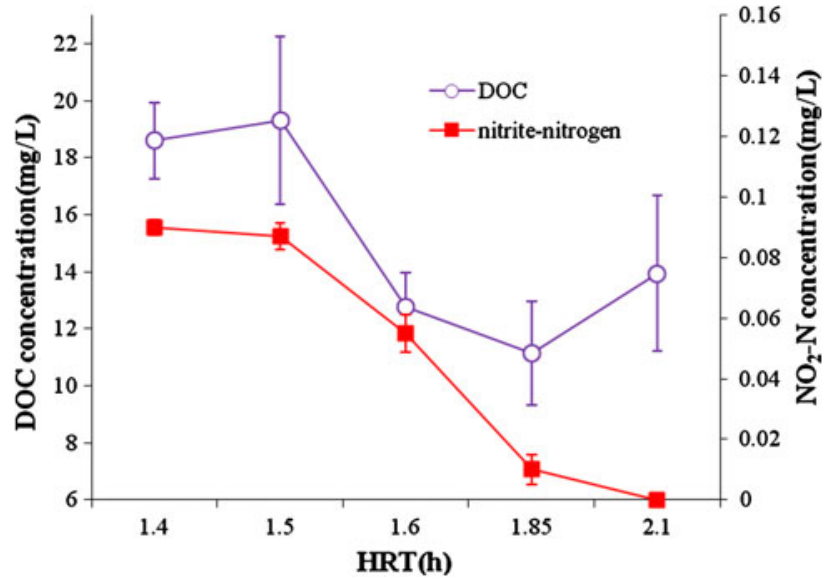

Fig. 7 Effects of HRT on DOC and $\mathrm{NO}_{2}-\mathrm{N}$ concentrations in the effluent with $50 \mathrm{mg} / \mathrm{L}$ of $\mathrm{NO}_{3}-\mathrm{N}$ in the influent ( $Y$ error indicates the standard error of means among three determinations)

provide sufficient carbon source for nitrite reduction, and reduce the accumulation of nitrite in the effluent.

When HRT was maintained in the range between 1.6 and $2.1 \mathrm{~h}$, DOC concentrations in the effluent differed little from each other, ranging between about 11 and $14 \mathrm{mg} / \mathrm{L}$. An increase in DOC concentration close to $20 \mathrm{mg} / \mathrm{L}$ was observed as HRT was lower than $1.5 \mathrm{~h}$ (Fig. 7). This may be attributed to a fast flow rate causing relatively high amounts of DOC to be washed out of the reactor.

Denitrification process supported by BSW caused high bacterial counts $\left(10^{4} \mathrm{CFU} / \mathrm{mL}\right)$ and DOC concentration $(10-20 \mathrm{mg} / \mathrm{L})$ in the effluent as same with other solid carbon sources, resulting in offended drinking water standards; therefore, post treatment is needed to remove DOC and bacteria in the effluent before human consumption. Activated carbon adsorption, sand filter, and disinfection were proposed as the effective post treatment measurements (Soares and Abeliovich 1998; Aslan and Turkman 2005; Ghafari et al. 2008).

A comparison in denitrification rates of different solid carbon sources

Denitrification rates are strongly dependent on the type of organic carbon source (Elefsiniotis et al. 2004), except for the HRT as indicated in the section "Effect of HRT on denitrification performance". As shown in Table 1, denitrification rate based on the use of BSW is far higher than that of natural organic solid substrates (NOSS), such as wheat straw and cotton, reported in the literatures, and is compared with PHB and PCL. As pointed out by Boley et al. (2000) and Hiraishi and Khan (2003), PHB and PCL are perhaps the most suitable solid substrates for denitrification process; however, the relatively high denitrification cost compared with a traditional liquid substrate such as methanol is a major problem, which hinders them from being used in practice. In comparison to PHB and PCL, the BSW-using denitrification is economically more attractive. Especially, with BSW being used widely in human lives, the re-use of waste BSW can be taken into account for denitrification processes.

\section{Conclusion}

The results in this research demonstrate that nitrate can be effectively eliminated from contaminated groundwater using a continuous flow reactor packed with BSW as carbon source and biofilm support. The indigenous microorganisms in groundwater proliferated readily under the denitrifying conditions and resulted in the stable biofilm formation onto BSW. Therefore, the denitrification process

Table 1 Summary of denitrification rates achieved with various solid carbon sources

\begin{tabular}{llllll}
\hline Carbon source & System description & Temperature $\left({ }^{\circ} \mathrm{C}\right)$ & $\begin{array}{l}\mathrm{NO}_{3}-\mathrm{N} \\
\text { inlet }(\mathrm{mg} / \mathrm{L})\end{array}$ & $\begin{array}{l}\text { Denitrification } \\
\text { rate [mg/(L h)] }\end{array}$ \\
\hline Wheat straw & Continuous & $25 \pm 1$ & 22.6 & 2.21 & References \\
Cotton & Continuous & $25 \pm 1$ & 22.6 & 2.31 & Soares et al. 1998 \\
Newspaper & Continuous & $25 \pm 1$ & 22.6 & 1.54 & Volokita et al. 1996b \\
Cotton & Continuous & $24 \pm 1$ & 68 & 3.38 & Volokita et al. 1996a \\
Giant reed & Batch & $21-24$ & 100 & 0.54 & Ovez et al. 2006 \\
Giant reed & Continuous & $21-24$ & 100 & 4.23 & Ovez et al. 2006 \\
Liquorice & Batch & $20-24$ & 100 & 0.86 & Ovez et al. 2006 \\
Liquorice & Continuous & $20-24$ & 100 & $7-96$ & Ovez et al. 2006 \\
PHB & Continuous & $20-25$ & $5-40$ & $21-166$ & Boley et al. 2000 \\
PCL & Continuous & $20-25$ & $5-40$ & 50 & Boley et al. 2000 \\
PBS & Continuous & $25-30$ & 50 & 27.9 & Zhou et al. 2006 \\
BSW & Continuous & $24 \pm 2$ & & This paper \\
\hline
\end{tabular}


supported by BSW is not necessary to inoculate with external microorganisms as carried out in the conventional denitrification process.

Denitrification rate using BSW was far higher than other natural organic substrates applied in denitrification process of drinking water to date, and was compared with PHB and PCL. BSW dominates over PHB and PCL in its low cost. The complete removal of $50 \mathrm{mg} / \mathrm{L}$ of $\mathrm{NO}_{3}-\mathrm{N}$ was achieved in a 23-day-old reactor. The highest volumetric rate based on the use of BSW reached up to $27.7 \mathrm{mg} \mathrm{NO}-\mathrm{N} /(\mathrm{L} \mathrm{h})$ with $1.5 \mathrm{~h}$ of HRT.

Acknowledgments The authors are grateful to the National Natural Science Foundation of China (Grant No. 21077014, 59978020), China Postdoctoral Science Foundation (Grant No. 20070420357), the Special Funds for Creative Team of Modern Agricultural System of Beijing, and the Special Program for Creative Ability of Beijing Academy of Agriculture and Forestry Sciences for their financial support.

\section{References}

Aslan S, Turkman A (2005) Combined biological removal of nitrate and pesticides using wheat straw as substrates. Process Biochem 40:935-943

Aslan S, Turkman A (2006) Nitrate and pesticides removal from contaminated water using biodenitrification reactor. Process Biochem 41:882-886

Bandpi MA, Elliott DJ, Memeny-Mazdek A (1999) Denitrification of groundwater using acetic acid as a carbon source. Water Sci Technol 40:53-59

Behera SK, Rene ER, Murthy DVS (2007) Performance of upflow anoxic bioreactor for wastewater treatment. Int $\mathrm{J}$ Environ Sci Tech 4:247-252

Bidhendi GRN, Nasrabadi T, Vaghefi HRS, Hoveidi H (2006) Biological nitrate removal from water resources. Int J Environ Sci Tech 3:281-287

Boley A, Müller WR, Haider G (2000) Biodegradable polymers as solid substrate and biofilm carrier for denitrification in recirculated aquaculture systems. Aquacult Eng 22:75-85

Chen X, Wu H, Wo F (2007) Nitrate vertical transport in the main paddy soils of Tai Lake region, China. Geoderma 142:136-141

Elefsiniotis P, Wareham DG, Smith MO (2004) Use of volatile fatty acids from an acid-phase digester for denitrification. J Biotechnol 114:289-297

Ghafari S, Hasan M, Aroua MK (2008) Bio-electrochemical removal of nitrate from water and wastewater-A review. Bioresour Technol 99:3965-3974

Gómeza MA, Hontoria E, González-López J (2002) Effect of dissolved oxygen concentration on nitrate removal from groundwater using a denitrifying submerged filter. J Hazard Mater B90:267-278

Green M, Schnizer M, Tarre S, Bogdan B, Shelef G (1994) Groundwater denitrification using an upflow sludge blanket reactor. Water Res 28:631-637
Hiraishi A, Khan ST (2003) Application of polyhydroxyalkanoates for denitrification in water and wastewater treatment. Appl Microbiol Biotechnol 61:103-109

Hoek JP, Klapwijk A (1987) Nitrate removal from ground water. Water Res 21:989-997

Jin Z, Chen Y, Ogura N (2004) Denitrification of groundwater using cotton as energy source. J Agro Environ Sci 23:512-515

Kesseru P, Kiss I, Bihari Z, Polyak B (2003) Biological denitrification in a continuous-flow pilot bioreactor containing immobilized Pseudomonas butanovora cells. Bioresour Technol 87:75-80

Mohseni-Bandpi A, Elliot DJ (1998) Groundwater denitrification with alternative carbon sources. Water Sci Technol 38:237-243

Moreno B, Gómez MA, González-López J, Hontoria E (2005) Inoculation of a submerged filter for biological denitrification of nitrate polluted groundwater: a comparative study. J Hazard Mater B117:141-147

Ovez B (2006) Batch biological denitrification using Arundo donax, Glycyrrhiza glabra, and Gracilaria verrucosa as carbon source. Process Biochem 41:1289-1295

Ovez B, Ozgen S, Yuksel M (2006) Biological denitrification in drinking water using Glycyrrhiza glabra and Arunda donax as the carbon source. Process Biochem 41:1539-1544

Rocca CD, Belgiorno V, Meric S (2007) Overview of in situ applicable nitrate removal processes. Desalination 204:46-62

Shrimali M, Singh KP (2001) New methods of nitrate removal from water. Environ Pollut 112:351-359

Sierra-Alvarez R, Beristain-Cardoso R, Salazar M, Gomez J, RazoFlores E, Field JA (2007) Chemolithotrophic denitrification with elemental sulfur for groundwater treatment. Water Res 41:12531262

Soares MIM, Abeliovich A (1998) Wheat straw as substrate for water denitrification. Water Res 32:3790-3794

State Environmental Protection Administration of China (SEPAC) (2002) Monitoring and analysis methods of water and wastewater, 4th edn. China Environmental Science Press, Beijing

Volokita M, Abeliovich A, Soares MIM (1996a) Denitrification of groundwater using cotton as energy source. Water Sci Technol 34:379-385

Volokita M, Belkin S, Abeliovich A, Soares MIM (1996b) Biological denitrification of drinking water using newspaper. Water Res 30:965-971

Vosoughifar HR, Shamsai A, Ebadi T (2005) Discretization of flow contain nitrate in porous media by finite volume technique. Int $\mathrm{J}$ Environ Sci Tech 1:317-323

Wang XM, Wang JL (2009) Removal of nitrate from groundwater by heterotrophic denitrification using the solid carbon source. Sci China Ser B Chem 52:236-240

Wang H, Qu J, Lei P (2002) Electrochemical hydrogen and sulfur autotrophic denitrification combined process in drinking water treatment. Acta Scientiae Circumstantiae 22:711-715

Wang D, Lin J, Sun R (2003) Optimum nitrogen rate for a high productive rice-wheat system and its impact on the ground water in the Taihu Lake area. Acta Pedol Sin 40:426-432

Zhou H, Wang J, Zhao X (2006) Denitrification using PBS as carbon source and biofilm supporter: effect of $\mathrm{pH}$. Environ Sci 27:290-293 